Cultura e sociedade 


\title{
(Obs)cena e espetáculo em Carolina Maria de Jesus: reflexões a partir de seus manuscritos inéditos
}

VALERIA ROSITO ${ }^{I}$

\author{
Introdução
}

Pra dizer a verdade, tenho nojo deste diário.

(Carolina Maria de Jesus, 27 jun. 1960)

C OMEÇO por uma pergunta recorrente no meio acadêmico sobre as razões do crescente interesse pela escritora Carolina Maria de Jesus. Não raro, a questão é posta com certo espanto, como se nada mais houvesse a ser discutido sobre sua história e seus escritos, a não ser reiterá-los à exaustão - seja com tédio ou entusiasmo próprios daqueles/as para quem Quarto de despejo (QD) lacra um destino e encerra uma trajetória meteórica, esgotada no sucesso do milhão de exemplares vendidos e consumidos em traduções por mais de quarenta países e quase duas dezenas de línguas. É bem verdade que a inegável fecundidade do best-seller - entre cujas qualidades de produção se destacam as de acenar com uma seleção breve e ágil dos diários da escritora sacramentense (MG) - é combinada, no extremo da recepção, a um público leitor disposto a se "instruir" com relatos das "margens sociais", em primeira pessoa, desafiando os discursos dominantes e o imaginário social, regados por índices incontáveis do desenvolvimentismo e da dolce vita consequente (Meihy, 2004, passim).

Tal interesse parece estar também historicamente situado, se retrocedermos algumas décadas à sua publicação. Encontramos em Antonio Candido (2003) a defesa de que o apego aos projetos ideológicos pautados pelo "realismo social", em detrimento da elaboração formal, responde pelo pensamento de uma intelligentsia moderna e esclarecida - emergente entre os anos 1920 e 1940 (e, sugiro, com fôlego aos nossos dias) - para quem a fatura literária "tende a ser um embuste que atrapalha o enfoque certo da realidade" (Candido, 2003 , p.196-7). Se naquele momento os chamados "delegados da coletividade", em eco ainda a Candido, falavam pelos subalternos, pode-se reclamar o pioneirismo de Audálio Dantas, jornalista e editor de Carolina Maria de Jesus, que desloca não somente os holofotes, mas também o autofalante para a própria figura à margem, obviedade expressa desde o subtítulo do livro "diário de uma 
favelada". A tendência chega ao paroxismo no século XXI em outras linguagens, como a cinematográfica, quando produções como Cidade de Deus (2002) ratificam a ilusão da narrativa sem mediação, da autenticidade das primeiras pessoas da fala, da prioridade ou, talvez ainda, da verdade dos "lugares-de-fala-de-primeira-pessoa" (Rosito, 2004).

Em associação a tal naturalismo atávico e historicamente situado, que pode explicar parcialmente o interesse corrente na escritora em tela, não se pode negligenciar ainda as conquistas sociais oriundas do processo de redemocratização, a começar pela Constituição Cidadã de 1988. Ativismo e movimentos sociais impulsionaram a promulgação das leis n.9.394/96 e n.10.639/03, inclusivas de disciplinas relacionadas ao ensino de história e cultura afro-brasileiras e africanas e vêm gerando consequências sobre o imaginário social, sobre os quadros docentes e discentes, e sobre o contingente de pesquisadores e interessados/ as em narrativas "rasuradas", ou no "tempo saturado de agoras", se desejarmos nos aproximar da diç̧ão de Walter Benjamin (1994b). O fenômeno, no entanto, parece se revestir de uma figuração dupla e, em alguma medida, conflitante. Por um lado, sem dúvida, ganham fôlego projetos de pesquisa que se voltam para os manuscritos inéditos, espalhados pelo menos por quatro instituições de guarda no Brasil (Barcellos, 2015); por outro lado, a própria força do best-seller, já comentada, irriga o desejo e/ou a conveniência de imaginar uma Carolina unidimensional - como mártir ou heroína - em outras palavras, merecedora mais de uma hagiografia do que de relatos povoados por suas contradições, por seus discursos deslocados, por sua identidade performática, ou seja, por tudo o que, ao fim e ao cabo, possa torná-la prismática e desconfortavelmente humana.

Por último, mas não menos importante, cabe ainda apontar o pioneirismo inestimável de dois historiadores - José Carlos Sebe Bom Meihy e Robert Levine - que receberam de Vera Eunice, filha da autora, nos anos 1990, dezenas de cadernos manuscritos. Em parceria, a dupla de intelectuais firmou um convênio entre a Fundação Biblioteca Nacional e a Library of Congress para tratamento do material, uma parte do qual em estado avançado de deterioração, e sua subsequente microfilmagem (Meihy; Levine, 1996). A disponibilização do material caudaloso - para nos restringirmos somente a esse acervo - abre comportas para uma miríade de tipos e gêneros textuais que vão desde centenas de páginas diarísticas descartadas na edição de $Q D$ até um rol de peças teatrais, romances, contos provérbios, humor e canções. Revela-se aí um imaginário muito mais complexo e denso, por onde passam narrativas surpreendentes, todas eivadas por índices temáticos com interseções não menos desconcertantes de gênero, raça e classe social. Ressalte-se que tal inesperado - então ou agora - deriva justamente da não conformidade da escritora a projetos alheios à sua visão de mundo, viessem de editores, políticos, amantes, movimentos negros, entre outros. ${ }^{1}$ Posto de outra forma, além de contribuir para enriquecimento das crônicas de uma época, a coleção de material descartado para as edições de seus diários escancara tensões singulares de uma mulher negra e pobre, e rastreia um 
arco muito mais amplo de subjetividades periféricas, que, entre atônitas, ativas e/ou cooptadas, fazem seu début numa pós-modernidade herdeira do colapso do projeto moderno de nação.

A esse respeito, aponte-se que a capital paulista, que já sediara manifestos modernistas três décadas antes, torna-se, na subjetividade da mineira, o Eldorado de onde poderia ver a distância seus percalços do passado na pequena cidade natal. Nela conhecera o encarceramento quando lia um grosso dicionário prosódico, confundido com o livro de feitiçaria de São Cipriano (Jesus, 2007, p.219); fora em Sacramento (MG) também que suas pernas perenemente em chagas não encontravam diagnóstico ou tratamento, fato também motivador de sua migração. Ao contrário, a organização do trabalho no meio urbano em andamento na proximidade dos anos 1940 fazia brilhar mais ainda a expectativa de sucesso na metrópole paulista: "A cidade de São Paulo era a sucursal do Paraíso. Algum dia irei! E este dia chegou: Dia 31 de janeiro de 1937, eu deixava Franca com destino a São Paulo" (IMS. CL. Acervo CMJ. Caderno 01, p.45-46). Em seu imaginário mitificado "é em São Paulo que os jovens vão instruir-se para transformar-se nos bons brasileiros de amanhã” (Jesus, 2007, p.248).

Em suma, se o projeto migratório para São Paulo se sustentava no sonho de assimilação e ascensão social pela ilustração, possível na metrópole, não se pode omitir ou subavaliar o relevo dado ao campo em suas memórias inscritas em cadernos preservados, que deram origem ao seu Diário de Bitita (Jesus, 2007), póstuma e originalmente publicado em tradução para o francês, na França como Journal de Bitita, em 1982: "Eu nasci no mato e me criei na roça. Foi o único período de minha vida que fui feliz. Eu ainda tenho saudades do tempo que fui menina os dias eram sempre iguais. Aqui é bonito! Vêja! Quando não se pode viver na cidade devemos viver na roça. Na roça pode construir um ranchinho, fura um pôço criar galinhas, porcos e até vacas [...]" (IMS. CL. Acervo CMJ. Caderno 01, p.16-17).

Antes de passarmos à próxima seção, nas quais focalizo as questões propriamente teóricas dessas considerações, cumpre ainda observar que o fenômeno contemporâneo da generalização de subjetividades fantasmáticas e de desarticulação do tempo parece encontrar sua gênese, no caso de Carolina Maria de Jesus, profetizada na própria concepção do que deveria se configurar como uma sequência teleológica da trajetória da autora de Quarto de despejo a Casa de alvenaria. É do historiador José Carlos Sebe Bom Meihy também o alerta sobre duas partes que compreendem a edição final de $Q D$. A primeira delas com apenas quatorze entradas de 15.7.1955 a 28.7.1955, chamada por ele de "espontânea"; e a segunda, de 2.5.1958 a 1.1.1960, denominada "provocada" (Meihy, 2017 , p.260). Tratar-se-ia lá do material já registrado pela autora quando de seu primeiro encontro com o jovem jornalista, e, em seguida, colada com a seleção feita por ele dos diários "encomendados" a partir da concepção do projeto em 1958, três anos depois. Os efeitos dessa profissionalização da escritora terão lugar mais adiante em nossa discussão. 
A relevância da observação do historiador torna-se cristalina aos/às que enveredam pelos manuscritos da escritora, cujas páginas diarísticas desvelam interesses extremamente antagônicos aos seus próprios, aqueles expressos no que passo a chamar de "tempo do espetáculo", e/ou "da mercadoria", com efeitos deletérios sobre o "tempo do desejo". Para dar um pouco mais de concretude à sugestão, vale a reprodução de um trecho de sua conversa com o ilustrador do livro: "Eu disse-lhe [ao sr. Dilnério, ilustrador] que estou concluindo uns romances que iniciei a tempos Aconselhou-me para escrever ao Diário. Que é um estilo que agrada" (FBN. DM. Coleção VE. MS 565, 3 jun.1960). Aponte-se que tanto sua frase na epígrafe a esta introdução quanto o comentário na citação anterior são proferidos dois meses antes da publicação de $Q D$ em agosto, comprovantes da realização da escritora do Canindé das regras de um jogo cujos aparentes benefícios a si própria ela já se punha a contestar. De que maneira sua cooptação a uma sequência biográfica "testemunhal" acaba por expor fraturas no esforço editorial de se constituir uma ontologia de gênero, primeira pessoa e classe social?

\section{Considerações teóricas}

É com âncora no pensamento marxista sobre reificação, alienação e fetichismo da mercadoria que considerável parte de formulações que nos interessam sobre a pós-modernidade se desenvolve. Tomarei somente aquelas de três teóricos cujas linhas referenciam contundentemente o povoado de espectros que assombram, e não raro, substituem, as subjetividades contemporâneas, em sua passagem inexorável para o "mundo das coisas": Giorgio Agamben (2009), Silviano Santiago $(2002 ; 2004)$ e Georg Lukács (2003). Começaremos pelo filósofo italiano em vista de sua forma mais abstrata de esculpir a condição contemporânea. Em seguida, acompanharemos o crítico brasileiro, em suas periodizações mais específicas de delimitar a pós-modernidade no tempo e no espaço; e concluiremos com o pensador húngaro George Lukács, por sua estreita e imediata afiliação ao pensamento marxista e aos conceitos a que recorremos.

Agamben (2009) não economiza imagens e metáforas - muitas de procedência benjaminiana - para retratar as mutações centrais nas categorias de tempo e espaço, próprias da condição contemporânea, que ele se põe a caracterizar. Para isso, são centrais suas referências à disjunção entre passado e presente em imagens poéticas de um dorso fraturado, que traduzem o que ele chama de "tempos não vividos" (Agamben, 2009, p.70). São traumas, silenciamentos e rasuras os constituintes centrais dessa "não vivência" referenciada. Experiências interditadas à revisitação e narrativização não encontram linearidade nos diversos segmentos temporais da história; não perfazem o circuito necessário entre o lembrar e o esquecer para o estabelecimento de uma memória coletiva. Aquilo que está impedido de se encontrar com sua origem retorna ad aeternum, por outro lado, ao presente, sem nunca coincidir tampouco com ele. $\mathrm{O}$ resultado final dessa não coincidência - entre o "não vivido" e as demandas do presente - por seu turno, não pode senão se manifestar em subjetividades fantasmáticas e em suas relações 
metonímicas, expressas na parte pelo todo - as mesmas observadas na relação fetichista que estabelecemos com o mundo das mercadorias. Outra imagem sua fértil a essa discussão diz respeito à sugestão de que tal e qual a incapacidade humana de apreender a luz quando em velocidade vertiginosa, o efeito de escuridão e cegueira é tão inevitável quanto é absoluta a certeza conferida pela astrofísica de que se trata, antes, de uma "ilusão de óptica”. Tentando uma aproximação menos abstrata com nosso corpus, não parece equivocado sugerir que a circulação frenética de informação e a visibilização excessiva de notícias parecem produzir mais facilmente sombras sobre os objetos focalizados do que a iluminação de seus contornos mais íntimos. Seria o caso do projeto editorial quarto-casa? Prossigamos.

No caso de Silviano Santiago (2004), elementos mais pontuais e contextuais são evocados para periodizar a pós-modernidade no Brasil no triênio 1978-1981. O silenciamento e a supressão de narrativas coletivamente traumáticas sem elaboração ou "escoamento" aos dias presentes são historicamente localizadas na violência do Estado nos anos ditatoriais (1964-1985). O quadro vivido desde 2018 no país, 32 anos depois da escrita do ensaio em 1986, não poderia prestar melhor testemunho - ou ter sido mais bem profetizado - nas considerações do analista brasileiro. Na perspectiva dos 21 “anos de chumbo", corpos foram literalmente desarticulados e mutilados na longa passagem de um projeto de nação à regência do mercado; o elo de continuidade entre passado e presente foi rompido, e as próprias narrativas dos exilados políticos, no retorno ao país, serviram mais ao propósito de colocá-los na lista dos mais vendidos pelas aventuras que protagonizaram do que propriamente ao de elaborar o luto pelo “passado não vivido” (Avelar, 1999).

Aos propósitos deste artigo, é digno ainda de ênfase o apontamento de Santiago (2002) sobre a primazia da sensibilidade óptica na substituição da capacidade narrar - nos termos do narrador "clássico", descrito por Walter Benjamin (1994a). O narrador é alçado ao status de espectador, na medida em que lhe resta observar a si mesmo e ao mundo, dada a impossibilidade de estabelecer com esse uma troca produtiva - no diálogo ou na narrativa. Em sua discussão relativa à ficção do final dos anos 1960, são significativas as retratações de choques geracionais em que a incomunicabilidade entre "velhos" $\mathrm{e}$ "jovens" torna-se regra e matriz dos anos vindouros. Crescem também as aparições de personagens jornalistas na ficção, para quem o "furo" de reportagem se sobrepõe à dimensão ética da notícia (Santiago, 2002, p.49). Por fim, é transfigurada a própria fatura literária, que passa a incorporar velocidade e proximidade de seus objetos antes capturáveis somente pela câmera. No processo generalizado de alienação e geração de fantasmagoria, as narrativas suprimem as marcações gráficas que usualmente separavam as falas de personagens íntegros.

Se encontramos em Lukács as pontes mais próximas e imediatas com o pensamento marxista, em vista da primeira publicação em 1923 de História e consciência de classe, não se pode deixar de sublinhar lá também a ênfase dada às práticas jornalísticas, com respeito aos conceitos de reificação e fetichismo da 
mercadoria. Ao afirmar a criação de uma estrutura econômica unificada pelo capitalismo, Lukács (2003, p.222) passa a defender que "os problemas de consciência relacionados ao trabalhador assalariado se repetem na classe dominante de forma refinada, espiritualizada, mas, por outro lado, intensificada". Ou seja, o processo de reificação e fetichismo é verticalizado e o fenômeno do desdobramento das subjetividades em versões espectrais de si implica sua assunção do status de "espectador do devir social", nos termos do filósofo húngaro - o que vale dizer, implica sua incapacitação para dirigir os rumos de sua história. No que tange especificamente os efeitos mais devastadores do processo discutido, o pensador é definitivo quanto às ocupações e às práticas a eles mais sensíveis:

Essa estrutura mostra-se em seus traços mais grotescos no jornalismo, em que justamente a própria subjetividade, o saber, o temperamento e a própria faculdade de expressão tornam-se um mecanismo abstrato, independente tanto da personalidade do "proprietário" quanto da essência material e concreta dos objetos em questão, e que é colocado em movimento segundo leis próprias. A “ausência de convicção" dos jornalistas, a prostituição de suas experiências e convicções só podem ser compreendidas como ponto culminante da reificação capitalista. (ibidem, p.222-3)

Atente-se para o fato de que, aos olhos de Lukács, a prática jornalística escancara a fusão mais emblemática do mundo subjetivo - das faculdades espirituais, com o mundo objetivo - das coisas. No momento em que a matéria jornalística se torna também uma mercadoria, o/a próprio/a elaborador/a de notícias perde a capacidade de se separar da matéria bruta sobre a qual se volta, e torna-se ele/a mesmo/a também sujeito/a ao processo de reificação:

A metamorfose da relação mercantil de um objeto dotado de uma “objetivação fantasmática" não pode, portanto, limitar-se às transformações em mercadoria de todos os objetos destinados à satisfação das necessidades. Ela imprime sua estrutura em toda a consciência do homem; as propriedades e as faculdades dessa consciência não se ligam mais somente à unidade orgânica da pessoa, mas aparecem como "coisas" que o homem pode "possuir" ou "vender", assim como todos os objetos do mundo exterior. E não há nenhuma forma natural de relação humana, tampouco alguma possibilidade para o homem fazer valer suas "propriedades" físicas e psicológicas que não se submetam, numa proporção crescente, a essa forma de objetivação. (ibidem)

Seja por meio da produção de uma "biografia das coisas", seja por meio do subjetivismo alienado do mundo, cai por terra a distância "épica" entre o eu e o mundo, nos termos do pensador. A esse respeito e para finalizar, parece-me oportuno ainda o recurso a outro escrito do mesmo pensador voltado para os efeitos específicos do avanço do capitalismo sobre a composição ficcional. Lançando-se num primeiro momento sobre a composição homérica, Lukács elabora uma passagem específica da Ilíada, que reproduzo a seguir, sobre a relação indivisível entre o heroísmo de Aquiles e sua relação com seus objetos: 
Sólido forma o escudo, ornado e vário

De orla alvíssima e triple, donde

Argênteo Boldrié pende, e lâminas tem

cinco. Com dedáleo primor, divino engenho,

Insculpiu nele os céus e o mar e a terra;

Nele as constelações, do pólo engastes,

Oríon valente, as Híadas, as Pleias,

A Ursa que o vulgo denomina Plaustro,

A só que não se lava no Oceano.

(Disponível em: <http://pt.wikisource.org/wiki/Anexo:Imprimir/

Il\%C3\%ADada_(Odorico_Mendes) >. Acesso em: 3 jan. 2012)

Lukács (1965, p.73-4) aponta a descrição detalhada por Homero de cada objeto, que os vincula historicamente a seus usuários. Ambos possuem uma história própria, não são mercadorias que possam ser descartadas ou substituídas aleatoriamente; ao contrário, são legados históricos e singulares de quem os porta. Integram o conjunto coeso do corpo do herói em suas várias partes, como dão testemunho as próprias armas de Aquiles.

\section{Desenvolvimento}

Sobre o aceno já feito a respeito da profissionalização de Carolina Maria de Jesus como repórter, parte de Audálio Dantas, seu editor, a contundente assertiva de que "repórter nenhum, escritor nenhum poderia escrever melhor aquela história - a visão de dentro da favela" (Jesus, 2006, p.3). O que as linhas de sua apresentação na $8^{\mathrm{a}}$ edição de $Q D$ se abstêm de contar são as condições de produção da parte "provocada” do diário, na dicção de Meihy (2017). Muito mais do que apenas acrescentar "à repetição da rotina favelada” que se provava "exaustiva", merecendo os cortes feitos (Jesus, 2006, p.3), o material descartado, como já apontado acima, espelha os efeitos da prática jornalística no processo mais universal de reificação dos corpos e fetichização das relações intersubjetivas - processo esse já avançado, nos idos de 1958.

Um roteiro breve pode nos assistir na visita a algumas amostras dos manuscritos inéditos de nossa escritora, com vistas a constatarmos os "dois tempos" experimentados por ela: o "do desejo" e o “da mercadoria" - aquele, o de suas incoerências e deslocamentos; este, o do consumo de suas narrativas domesticadas. Pode-se começar por alguns dos incontáveis trechos em que Carolina Maria de Jesus referencia a escrita de seus outros gêneros, muitos dos quais desenvolvidos simultaneamente à escrita dos diários e dividindo com esses, não raro, espaço nos mesmos cadernos. Em seguida, convém ilustrar a relação complexa da escritora com os meios de comunicação de massa, na medida em que reportagens sobre ela vêm a público antes mesmo da publicação de $Q D$.

Começo por ressaltar a "índole estética” da escritora, apreensível no âmbito geral de sua escrita, inclusive aquela de seus diários, com abundantes observações quotidianas: "O Dr. Lelio tem o perfil de Olavo Bilac" (FBN. DM. 
Coleção VE. MS 565, 10 ago. 1960), no comentário sobre a aparência física de um dos jornalistas na redação; ou ainda "- quando a Dona Bibi Ferreira chegou fui falar-lhe. Ela pareçe franceza. O Audálio apresentou-me. Olhando-a eu idealisava uma peça para ela. Já havia pensado na peça e relatado o argumento ao Audálio" (FBN. DM. Coleção VE. MS 565, 14 ago. 1960), sobre a já célebre atriz brasileira; "E não gosto de sair aos sábados para não ver os pobres lamentar-se. Da impressão de estarmos vivendo os Misseraveis, de Victor Hugo", na metáfora e estetização da miséria que tão bem conhecia (FBN. DM. Coleção VE. MS 565, 11 jun. 1960); "tinha a impressão de estar vendo a personagem de um conto A Felizarda” (FBN. DM. Coleção VE. MS 565, 3 nov. 1960), na referência a uma personagem de um de seus romances. Cabe notar a profusão de verbos e expressões ligadas ao espetáculo ("olhando-a", "não ver”, "tinha a impressão", "vendo"), na abertura de cada comentário da escritora, como se não escapasse a ela a experiência do mundo como encenação.

Se as impressões corriqueiras de seu dia a dia são eivadas de citações literárias, sua produção não documental passa a concorrer com as exigências editoriais para a produção de diários, como já indicado. Parece mesmo que a experiência de aceleração do tempo no encontro com o jornalismo acirra ainda mais sua avidez por sua escrita não jornalística, satisfeita na ocupação do "tempo do desejo". Esse tempo é marcado pela própria ausência do relógio, declarada em "Eu não tenho relógio - Despertei às sete horas. Fiz café e o João foi comprar pão e preparar-me para ir à escola. Eu estou confusa [...]" (FBN. DM. Coleção VE. MS 565, l jun. 1960). Ou ainda "Liguei o radio para ouvir as horas" (FBN. DM. Coleção VE. MS 565, 18 dez. 1958). Ou seja, é seu ritmo biológico e "radiofônico" que dão compasso à sua rotina diária. Sobre a simultaneidade dos dois tempos, ainda destacam-se, entre outros, os trechos "passei o dia escrevendo o drama" (FBN. DM. Coleção VE. MS 565, 27 jun. 1960); e no mês do lançamento de $Q D$ reitera ainda "Eu estava escrevendo, finalizando um drama, quando dona Brasilia chegou” (FBN. DM. Coleção VE. MS 565, 4 ago. 1960). $\mathrm{Ou}$ ainda quando desvela seus planos em "Fui falar com o senhor Arlindo Caetano Filho que pretendia escrever monologos infantis e peças para crianças" (FBN. DM. Coleção VE. MS 565, 6 jun. 1960).

Por outro lado, sua profissionalização é pontuada, por exemplo, quando, no momento mesmo em que é entrevistada, troca de lugar com o repórter-entrevistador no cumprimento das direções de Audálio Dantas:

O repórter despédiu-se dizendo que tem hora para entregar o serviço.

O seu nome para o Diario? Sinão o Audálio repreende-me.

José Roberto da Pena.

O senhor esta estudando?

parece médico!

- o jornal não me da tempo. (FBN. DM. Coleção VE. MS 565, 15 jun. 1960) 
A passagem é emblemática porque ao proceder à troca de posições com o repórter, a escritora registra uma experiência comum a ambos e a todos/as. Percebamos que o "tempo da imprensa" pressupõe uma celeridade que compromete o "tempo do desejo" seja o de Carolina Maria de Jesus, seja o de seu entrevistador-entrevistado, que carece de tempo para estudar. Esse tempo do desejo ganha uma retratação somática e involuntária no corpo da escritora, observável em "A Poesia surgiu e fica na minha cabeça. pareçe que estou sonhando. Fico sem ação. Quando ela dessapareçe eu reanimo" (FBN. DM. Coleção VE. MS 565, 5 a 8 ago. 1960). A literatura-mercadoria causa-lhe desgosto: "Já estou desgostando da Litératura. pretendo desligar do Audálio se Deus quizer (FBN. DM. Coleção VE. MS 565, 8 ago. 1960); e ainda, na mesma época, "Eu não tenho tempo. Êles dão muito serviço. penso: todos arranjam emprêgo. Ninguem comenta o meu mister de escritora trouxe tantas confusões" (FBN. DM. Coleção VE. MS 565, 11 jun. 1960).

O "desgosto" pela literatura implica o afastamento de uma vocação - uma "chamada", em stricto sensu - na dicção romântica, uma "missão" mesmo, que a impele, em meio a suas entradas diarísticas, a acolher o que brota espontaneamente, como podemos ver a seguir:

p.11-7 (data 5 de dezembro de 1958)

O senhor Sousa é professôr.

Mas trabalha como servente de

p.11-8

pedreiro. $\mathrm{O}$ trabalho não regride

o valôr do homem porque eu

sou poetisa e vivo no lixo.

e estou vivendo. Hoje eu fiz

êste verso Eu não faço verso.

eles promanam na mente.

Eu sonhei que estava morta

Vi meu corpo num caixão.

Em vez de flores era um livro

Que estava na minha mão.

(Caderno 11, disponível em

<http://objdigital.bn.br/acervo_digital/div_manuscritos/mss1352132/

mss1352132.pdf > [grifos acrescentados. Cf fac-símile da página no Anexo I]

Em contraste flagrante com a perspectiva romântica a partir da qual a escrita é um dom, que se manifesta espontaneamente - "promana" -, os preparativos para o lançamento propriamente dito de $Q D$ envolvem uma montagem cênica da favela e da pobreza por parte da Livraria Francisco Alves em moldes neonaturalistas: "preparei umas latas para o Audalio preparar a vitrine. Demonstrando um quarto de despêjo" (FBN. DM. Coleção VE. MS 565, 13 maio 1960). Segue ainda: 
Quando chegamos na Livraria vi o meu quadro na porta

Estou desenhada no ponto grande da favela $\mathrm{O}$ que está escrito no quadro:

- Esta favelada Carolina Maria de Jesus escreveu um livro. Quarto de despejo.

A Livraria Francisco Alves oferece ao povo. (FBN. DM. Coleção VE. MS 565, 13 maio 1960)

A essa encenação, traduzida por Audálio Dantas, segundo a escritora, como "retrato fiel do que presencio durante o dia e incluo no meu diário" (FBN. DM. Coleção VE. MS 565, 23 ago, 1960), corresponde a forte contrariedade da escritora por estar sendo mantida na favela do Canindé, no desempenho de um papel afeito ao projeto editorial, mas absolutamente contrário às suas aspirações:

$\mathrm{Eu}$, estou ressentida com o Audalio porque êle aprisiona-me. E um preceptôr vou dessistir de escrever com êle. Eu tenho varias capacidades e êle não dêixa eu explorar as minhas habilidades. O senhor Lélio ouviu-me sorrindo e disse-me: a senhora esta enganada. Eu acho que o Audalio é seu amigo.

- Não crêio. Ele anula tudo que eu idealiso. se existe um élo ... chama-se Audalio! Ele quer alugar um quarto para mim Como é que eu posso morar num quarto com os meus filhos endiabrados. Da a impressão que eles são das selvas. (FBN. DM. Coleção VE. MS 565, 10 ago. 1960)

A disparidade entre os dois horizontes ou os dois "tempos" encontra seu clímax na entrada do diário de 30 de agosto de 1960, no momento da mudança da escritora da favela do Canindé para o bairro de Osasco, sob a curiosidade e agressividade de vizinhos e espetaculosidade da mídia:

Respirei aliviada quando o motorista chegou. O senhor Milton Bitencourt. Ele ficou recêioso quando viu os favelados aglomerados ao redor do barracão. pedi que fosse carregando os cacarecos para o caminhão. Eu estava agitada com réceio dos favelados roubar os meus livros. [...]

Os reportes iam chegando par filmar minha saida da favela.[...] Que confusão. E que nojo ao mesmo tempo. Mêsmo com a confusão estava contente. Era a concretisação de um sonho. Os reportes fotografaram e filmaram. O Audalio chegou com o reporte José Hamilton. A Dona Aliçe auxiliou-me a carregar os cacarecos. [...] O motorista estava agitado. A Meni surgiu e disse-me: Ve se não esquece dos pobres. [...] A Léila surgiu andando com dificuldade. Não veio para agradecer-me os favôres que prestei-lhe. Vêio para agitar e instigar os favelados. O motorista partiu com a marcha acelerada. [...] A Leila que envelhece mas e sempre infantil agitou-se pegou uma pedra e atirou dentro do caminhão. Eu olhava as pedras e a direção com receio de atingir os olhos da Vera e do Jose Carlos que já estavam firido com as pedradas.

[...]

O Audalio queria que eu despedisse das faveladas pegando-lhe nas mãos, gesto que eu reprovei porque a mão do favelado não tem poesia. Não ternura. Não sabe acariciar. [...] (FBN. DM. Coleção VE. MS 565, 30 ago. 1960). [Grifos acrescentados] 
O desejo editorial de retratar uma identidade comum entre a população desfavorecida do Canindé e a escritora, homogeneizando-as, é frustrado pela manifestação violenta dos/as moradores do Canindé, surpreendente em sua heterogeneidade; resta uma escritora desalojada de qualquer lugar social que the pudessem lhe reservar: seja o da favelada excepcional que poderia encarnar "a voz do povo", seja o da artista negra polivalente cuja singularidade desafiava seus pares, a intelligentsia e a própria mídia.

É bem verdade que a ação da mídia na espetacularização de Carolina Maria de Jesus tem efeitos contrastantes sobre a escritora à medida que - como venho insistindo - ela se dá conta de que sua escrita não diarística é rejeitada pelos editores em favor das páginas selecionadas de seus diários e não virá a lume sem aporte de recursos próprios, como realizou ainda em vida com Pedaços da fome (1963) ou pelo esforço de pesquisa de Meihy e Levine (1996), que organiza a Antologia pessoal duas décadas depois de sua morte. O efeito de cindi-la em uma versão espectral de si mesma cria, ao menos até a publicação do best-seller, percepções mistas sobre seu recém-adquirido status, a partir das quais encontramos passagens em que é flagrante sua euforia:

Quando iniciou o programa eu fui para o palco. Entre as meninas que iam tocar seléções de Dolores. A plateia estava lotada. Quando o senhor Durval anunciou-me eu entrei no palco. Ele disse que eu sóu a maior revelação litéraria

Ele entregou-me uma canêta de ouro presente dos produtos Kibon. - Aos produtos Kibon, o meu eterno agradecimento.

Eu són fan numero um dos sorvetes Kibon.

É bem fềito.

Não faz mal a ninguem. A massa e finissima. Duplamente filtrada. (FBN.

DM. Coleção VE. MS 565, 22.5.1960) [grifos acrescentados]

Não só o agradecimento a Kibon é proferido numa versão da escritora como MC e anunciante, sob holofotes televisivos e percepção de uma "plateia lotada", como também é seguido de considerações entusiasmadas de Carolina Maria de Jesus sobre seu futuro como celebridade: "Quando eu ganhei a canêta pensei: vou guarda-la. Vou estrea-la quando assinar o premio Nobel: Quem sabe ganho aquêle premio" (ibidem). Encenação semelhante pode ser observada poucos dias antes do programa:

Esquentei a comida e dei aos filhos ... E fui comprar genéros no empório do japonês na Avenida Tiradentes - Eles vendem mais barato. Mas o povo dava-me os parabens. Quando passo perto de um onibus ouço!

- Olha a mulher que escreve!

$\mathrm{E}$ os onibus diminui a marcha para os passageiros olhar-me.

Aos motoristas, o meu agradecimento. (FBN. DM. Coleção VE. MS 565, 17 maio 1960) [grifos acrescentados] 
Dessa feita na rua, observando-se a si mesma sendo observada, a mineira se lança num jogo de espelhos exponencializado pelos olhares entrecruzados. Carolina encena-se a si mesma diante da realização de sua cisão, de sua persona estelar e especular aos seus observadores. ${ }^{2}$

A título de finalização do passeio pelos inéditos de nossa escritora, registro ainda duas entradas no diário de 15 e 16 de abril de 1961, sete meses depois da publicação de $Q D$, quando era encenada a peça homônima do best-seller, com direção de Amir Haddad e Ruth de Souza no papel de Carolina Maria de Jesus:

Quando cheguei ao teatro fomos filmadas para a televisão. Cantamos eu dançei com o Audálio no palco. Estava presente a mulher, Ronaldo Tarok, sua esposa e outros. Voltamos de auto pra casa. Quando chegamos fomos avisar a vizinha que iamos passar na televisão quando ela ligou o canal quatro estava despedindo da Ruth. (FBN. DM. Coleção VE. MS 565, 15 abr. 1961) [grifos acrescentados]

Note-se que se por um lado, a escritora é fortemente mediatizada na época de sua ascensão, o aparelho televisivo, por outro, não integra o rol de eletrodomésticos da então moradora da casa de alvenaria. Ao contrário, a radiofonia tem centralidade em toda a sua trajetória, funcionando como substituta do relógio e meio de acesso à música e às ultrassentimentais novelas de rádio, que lhe dão régua e compasso para a escrita de suas próprias peças: "Hoje eu estou cansada e a vida que vae nos atrofiando. Os filhos estão contentes porque há o que comêr. Ouvi o drama da Record Madrasta. O título da peça" (FBN. DM. Coleção VE. MS 565, 13 de dez. 1962). ${ }^{3}$

Sobre sua nova etapa de vida fora da favela do Canindé, Carolina Maria de Jesus pontifica: "Eu pensava que a vida na casa de Alvenaria cheia de encantos e civismo - enganei: tenho a impressão que estou dentro do mar lutando para não afogar. Quando eu estava na favela, tinha ilusões de cá - pensava que isto aqui fôsse o paraiso" (FBN. DM. Coleção VE. MS 565, 15 abr. 1961). A passagem faz referência específica a um de seus sonhos, realizado então, mas contestado pela escritora, em confirmação a suas frustrações continuadamente expressas.

\section{Considerações finais}

As revelações dos manuscritos da lavra de Carolina Maria de Jesus, descartados por seus editores quando de sua organização para publicação, nos autorizam a entrar no diálogo com uma parte da crítica literária no Brasil a respeito [a] da longevidade do naturalismo e de seus lugares de fala privilegiados; [b] da periodização da pós-modernidade. Se acompanhamos Silviano Santiago na identificação dos anos pós-ditatoriais como marco inaugural da pós-modernidade no Brasil, a subjetividade de Carolina Maria de Jesus dá mostras de que podemos retroceder pelo menos em duas décadas em tal periodização, tratando-se, portanto, dos anos imediatamente anteriores aos "de chumbo". O intrincado processo de publicação e os efeitos deletérios de sua consequente carreira meteórica sobre sua sensibilidade atestam um alarmante processo de reificação a partir das 
relações travadas com a instituição do jornalismo, assim como com o gênero documental/testemunhal, na esteira agora da discussão proposta por Lukács. Tal problemática se configura exatamente no momento em que a autenticidade do testemunho das margens se desloca das terceiras para primeiras pessoas, com o protagonismo dos ocupantes do lugar periférico. As “vozes de dentro" são acentuadas no caso em tela pela narrativa em primeira pessoa da mulher negra e periférica. O efeito adicional que se pode identificar ainda no avanço da pós-modernidade diz respeito aos dois gumes da "arqueologia" como estratégia para suturar "dorsos quebrados", em eco a Agamben, desta vez. A reemergência nos nossos dias do "passado não vivido", das narrativas traumáticas silenciadas por e em todos os projetos "modernos", no entanto, parece também prosperar com um processo de lapidação dos ângulos mais inconvenientes e incoerentes dessas mesmas narrativas, num esforço perverso de produzir, de ouvir, ou de consolidar somente aquelas narrativas ou aqueles trechos que servem ao propósito de hagiografar tais testemunhas. Tratar-se-ia da "cegueira" decorrente da incapacidade de apreender a "luz" em velocidade, na dicção ainda do filósofo italiano? Merecerá Carolina uma nova interdição justo nos momentos em que luzes são lançadas sobre suas narrativas integrais?

\section{Notas}

1 A esse respeito e em resposta à outorga do título de cidadã paulistana em 28.9.1961, conquista sobretudos dos ativistas negros do Clube 220, Carolina Maria de Jesus discursa; "A transição da minha vida foi impulsionada pelos livros. Tive uma infância atribulada. Não me foi possível concluir o curso primário, mas desde que aprendi a ler passei a venerar os livros fantasticamente, lendo-os todos os dias [...] Se não fosse por intermédio dos livros que deu-me boa formação, eu teria me transviado, porque passei 23 anos mesclada com os marginais. [...] Devo agradecer aos brancos de São Paulo que deram oportunidade aos pretos, aceitando as nossas criações e acatando-nos no núcleo social. Este gesto contribui para abolir preconceitos raciais [...]" (Silva, 2011, pos 4862).

2 Em conferência intitulada "Second order observation historicized: na epistemological frame narrative", Hans Ulrich Gumbrecht referencia Niklas Luhmann como, senão o criador, mas o usuário produtivo da expressão “observação de segunda ordem”. Segundo consideração de Gumbrecht, o fenômeno se generaliza a partir da secularização do pensamento ao fim do século XVIII e início do século XIX, como "uma alternativa de estabelecer uma estrutura de significação a partir da constituição de uma autoimagem em meio a alternativas possíveis", decorrentes de um perspectivismo historicamente situado. (Disponível em: <http://www.design-in-human.de/lectures/gumbrecht. html>). A "modernidade" da generalização de tal fenômeno é então considerada anterior mesmo à própria revolução industrial, cujo circuito de mercadorias parece ensejar uma qualidade diversa na cisão do sujeito em seus duplos, na condição pós-moderna ou contemporânea. Neste último caso - ecoamos Walter Benjamin (1994c, p.196) quando pontifica que se trata do abandono pela humanidade dos deuses olímpicos, a quem eram dedicados os espetáculos, para entregar-se em espetáculo a si mesma. 
3 Como vimos acima, o rádio era sua mídia central. Nosso GP UFRRJ/CNPq Gedir Gênero, Discurso e Imagem produziu e estreou a peça "Salve Ela: Carolina de Jesus em Cena", na qual incorporamos integralmente o drama inédito de Carolina Maria de Jesus “Obrigado senhor Vigario), no Programa Persona III, na UFRRJ, em 2014, com a Cia. Os Ciclomáticos, direção de Ribamar Ribero. (Cf. Anexo II, figuras 1 e 2).

\section{Referências}

AGAMBEN, G. O que é o contemporâneo e outros ensaios. Trad. Vinícius Nicastro Honesko. Chapecó: Argos, 2009.

AVELAR, I. The Untimely Present: Postdictatorial Latin American Fiction and the Task of Mourning. Durham; London: Duke UP, 1999.

BARCELLOS, S. (Org.) Vida por escrito: guia do acervo de Carolina Maria de Jesus. Rio de Janeiro e Sacramento: Bertolucci, 2015.

. Portal biobibliográfico de Carolina Maria de Jesus. s.n.: s.d. Disponível em: <https://www.vidaporescrito.com/>.

BENJAMIN, W. O narrador. In: __. Magia e técnica, arte e politica: ensaios sobre literatura e história da cultura. 7.ed. Trad. Sérgio Paulo Rouanet. São Paulo: Brasiliense, 1994a. p.197-221. (Obras escolhidas v.1)

Sobre o conceito de história. In: Magia e técnica, arte e politica: ensaios sobre literatura e história da cultura. 7.ed. Trad. Sérgio Paulo Rouanet. São Paulo: Brasiliense, 1994b. p.222-32. (Obras escolhidas v.1)

. A obra de arte na era de sua reprodutibilidade técnica. In: Magia e técnica, arte e política: ensaios sobre literatura e história da cultura. 7.ed. Trad. Sérgio Paulo Rouanet. São Paulo: Brasiliense, 1994c. p.165-96. (Obras escolhidas v.1)

CANDIDO. A. A Revolução de 30 e a cultura. In: A educação pela noite e outros ensaios. 3.ed. São Paulo: Ática, 2003. p.181-98.

GUMBRECHT, H. U. Conferência "Second order observation historicized - an epistemological frame Narrative", proferida em 5.9.2015. Disponível em: <https:// schloss-post.com/second-order-observation-historicized/>. Acesso em: 3 abr. 2019.

HOMERO. Ilíada. Trad. Manuel Odorico Mendes. Disponível em: < http:// pt.wikisource.org/wiki/Anexo:Imprimir/Il\%C3\%ADada_

(Odorico_Mendes)> . Acesso em: 3 jan. 2012.

JESUS, C. M. de. Quarto de despejo: diário de uma favelada. 8.ed. São Paulo: Ática, 2006. . Diário de Bitita. 2.ed. Sacramento, Bertolucci, 2007.

LUKÁCS, G. Narrar ou descrever? Contribuição para uma discussão sobre o naturalismo e o formalismo. In: __ Ensaios sobre literatura. Coordenação e prefácio Leandro Konder. Rio de Janeiro: Civilização Brasileira, 1965. p.43-94.

História e consciência de classe; estudos sobre a dialética marxista. Trad. Rodnei Nascimento. Rev. Kerina Jannini. São Paulo: Martins Fontes, 2003.

MEIHY, J. C. S. B. Os fios dos desafios: o retrato de Carolina Maria de Jesus no tempo presente. In: SILVA, V. G. da. (Org.) Artes do corpo: memória afro-brasileira. São Paulo: Selo Negro, 2004. p.15-54. 
LUKÁCS, G. Repaginando Carolina Maria de Jesus. In: CHIARA, A. et al. (Org.) Bioescritas/biopoéticas corpo, memória e arquivos. Porto Alegre: Sulina, 2017. p.258-75.

MEIHY, J. C. S. B.; LEVINE, R. M. (Org.) Men estranho diário. São Paulo: Xamã, 1996.

ROSITO, V. Cinema cidadão e gênero “denúncia”: o caso Cidade de Deus. Revista Rio de Janeiro, v.12, p.175, 2004.

SANTIAGO, S. O narrador pós-moderno. In: Nas malhas das letras; ensaios. Rio de Janeiro: Rocco, 2002. p.44-60.

. A democratização no Brasil (1979-1981); cultura versus arte. In: $O \cos ^{-}$ mopolitismo do pobre. Belo Horizonte: Editora UFMG, 2004. p.134-56.

SILVA, M. A. M. da. A descoberta do insólito: literatura negra e literatura periférica no Brasil (1960-2000). Campinas, 2011. Tese (Doutorado) - Instituto de Filosofia e Ciências Humanas, Universidade Estadual de Campinas.

\section{Fontes}

FUNDAÇÃO BIBLIOTECA NACIONAL. Divisão de Manuscritos. Coleção Vera Eunice. MS 565. Citação no corpo deste trabalho: FBN. DM. Coleção VE. MS 565 [data]

INSTITUTO MOREIRA SALLES. Coordenadoria de Literatura. Acervo Carolina Maria de Jesus. Cadernos 1 e 2. Citação no corpo deste trabalho: IMS. CL. Acervo CMJ. [indicação do caderno e páginas]

Contribuíram com parte das transcrições referenciadas os estudantes em Iniciação Científica do Projeto Na Palma da Mão: intimidade e espetáculo em Carolina Maria de Jesus, dir. Valeria Rosito, GP CNPq/UFRRJ Gedir: Gênero, Discurso e Imagem: Alcione dos Santos, Ana Pereira, Anderson Rodrigues, Carla da Nóbrega, Crystiane Bispo, Daiane Maria Santos Borduan, Daniel Costa, Gleice Barboza, Jéssica Lemos, Mariana Valle de Mello, Raissa Loth, Rayane Távora e Thaís dos Santos.

RESUMO - Este artigo se volta para um recorte de manuscritos inéditos de Carolina Maria de Jesus, produzidos entre 1958 e 1962, que registram conflitos emergentes com sua profissionalização como "autora" para o projeto editorial protagonizado pelo seu best-seller. Trata-se do embate entre uma visão lapidada da "favelada" - como testemunha de primeira pessoa e "repórter" - ao contrário do desejo prismático da mineira pela escrita criativa e "descolada" dos referentes que lhe eram imediatos. O exame busca caracterizar [a] a pós-modernidade / contemporaneidade a partir de sensibilidades periféricas em interseção de gênero, raça e classe, em vista da desarticulação do tempo e de narrativas lineares (Agamben, 2009); [b] a exacerbação do exercício escópico (Santiago, 2002); e [c] os efeitos generalizados de tal intensificação traduzidos por subjetividades fantasmáticas, em acelerado processo de alienação, reificação e espetacularização (Lukács, 2003).

PALAVRAS-CHAVE: Carolina Maria de Jesus, Manuscritos, Contemporaneidade, Pós-modernidade, Subjetividades contemporâneas, Estudos subalternos. 


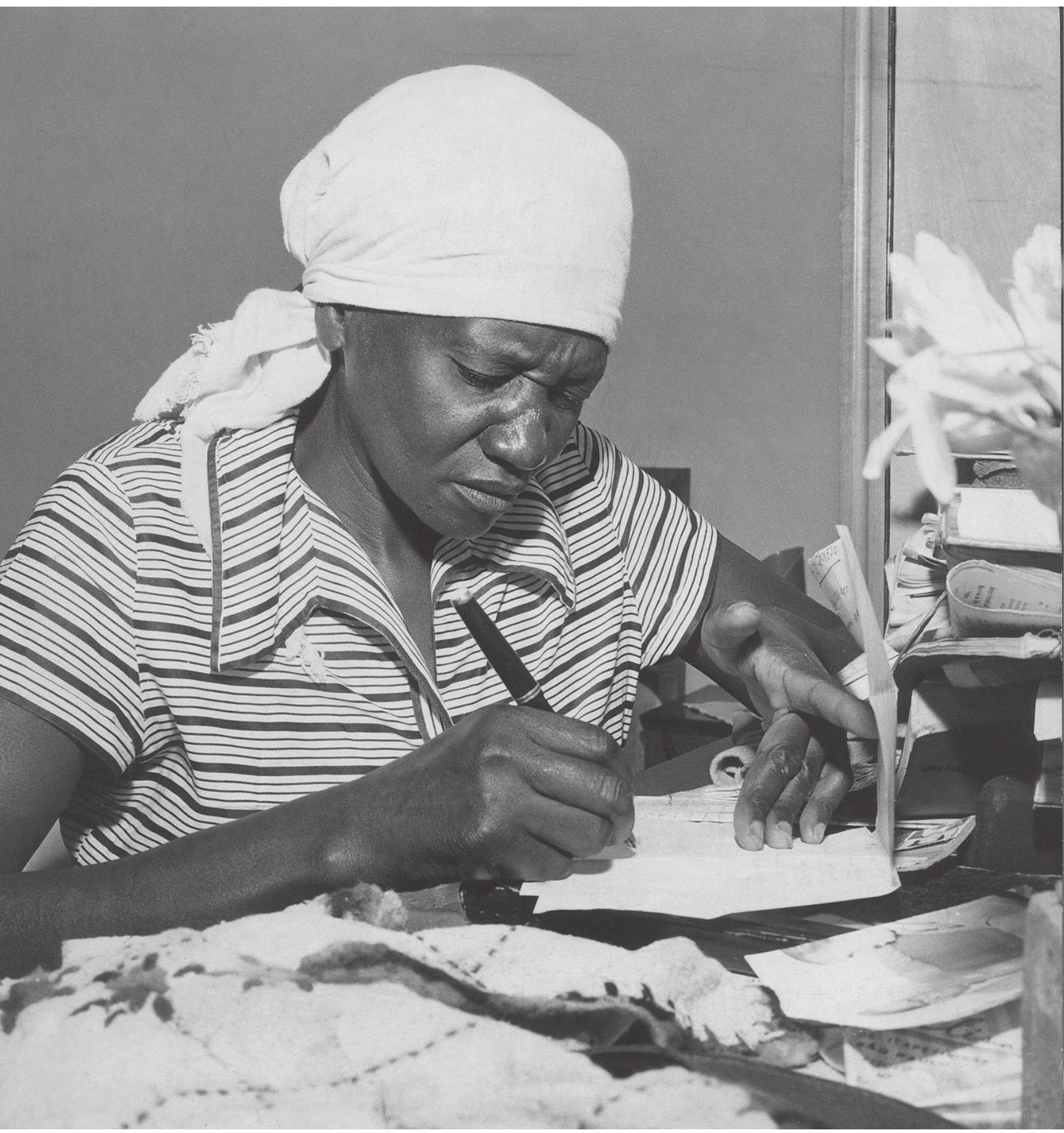

Carolina Maria de Jesus (1914-1977). 
ABSTRACT - This article examines unpublished manuscripts of Carolina Maria de Jesus produced between 1958 and 1962 that depict emerging conflicts regarding her professionalization as an "author" in the publishing project set in motion by her best-seller. It is a struggle between the lapidary outlook of a "slum dweller" - as a first-person witness and "reporter" - and her prismatic desire for creative writing, in many ways "detached" from her more immediated referents. This investigation seeks to characterize (a) post-modernity/contemporaneity appertaining to peripheral subjectivities in the intersections of gender, race, and class, in view of the disarticulation of time and of linear narratives (Agamben, 2009); (b) the exacerbation of the scopic exercise (Santiago, 2002); and (c) the overall effects of this intensification as translated by phantasmatic subjectivities in a rapid process of alienation, reification, and spectacularization (Lukács, 2003).

KErwords: Carolina Maria de Jesus, Manuscripts, Contemporaneity, Postmodernity, Contemporary subjectivities, Subaltern studies.

Valeria Rosito é professora associada de Literatura Brasileira na Universidade Federal Rural do Rio de Janeiro (UFRRJ) NI, Departamento de Letras e líder do GP CNPq/ UFRRJ Gedir, Gênero, Discurso e Imagem. @ - valeriarosito2@gmail.com / https://orcid.org/ 0000-0003-0956-6927.

Recebido em 27.5.2021 e aceito em 25.7.2021.

I Universidade Federal Rural do Rio de Janeiro, Departamento de Letras, Niteroi, Rio de Janeiro, Brasil. 


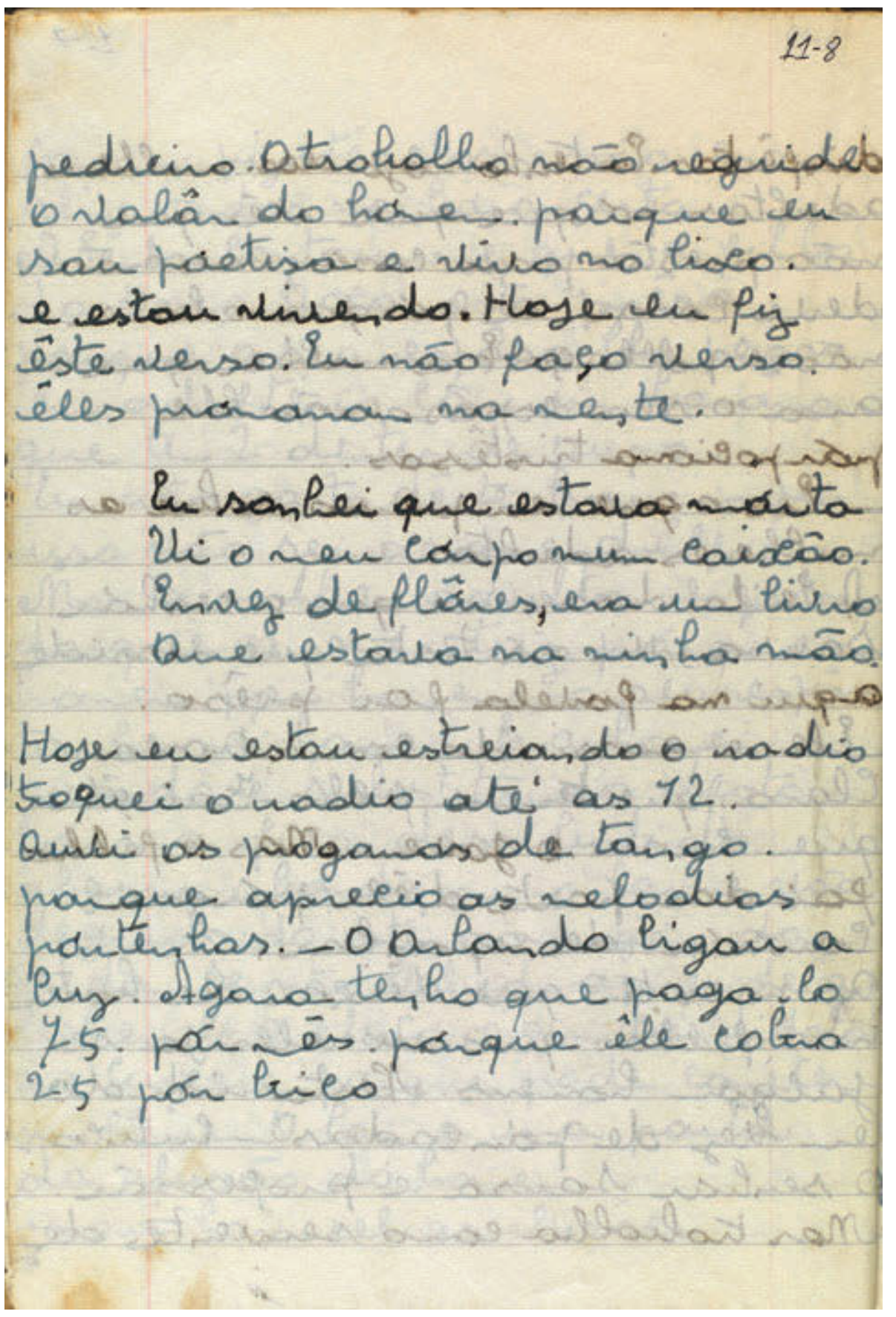

Página 8 do caderno 11 digitalizado pela FBN e disponível em: <http://objdigital. bn.br/acervo_digital/div_manuscritos/mssl352132/mssl352132.pdf>. 

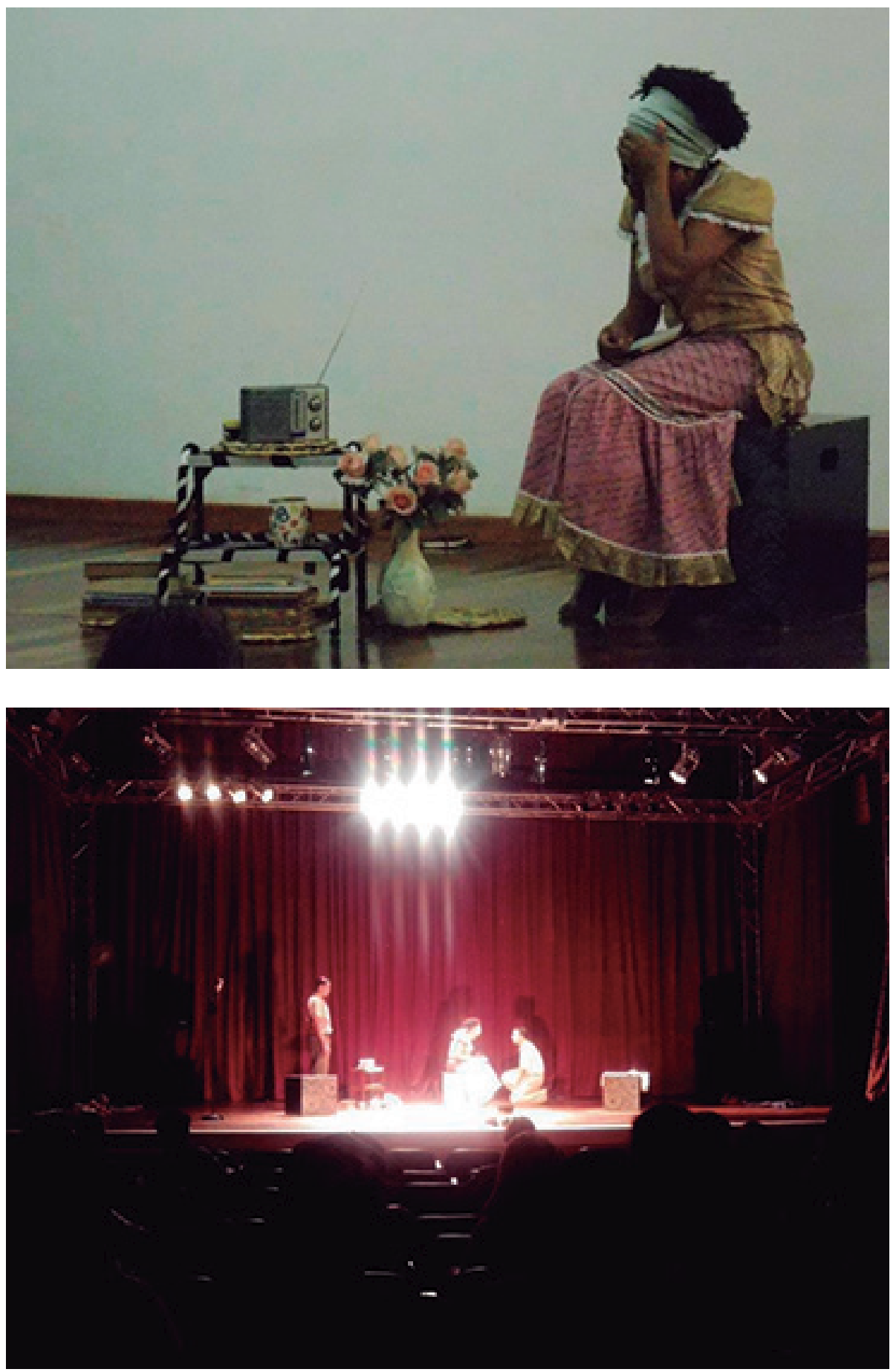

Estreia de "Salve Ela: Carolina Maria de Jesus em Cena", incorporando a peça inédita "Obrigado Senhor Vigário" em junho de 2014, nos palcos da Universidade Federal Rural do Rio de Janeiro. Peça disponível na íntegra em: <https://youtu. be/iatlWn_b4es>. 


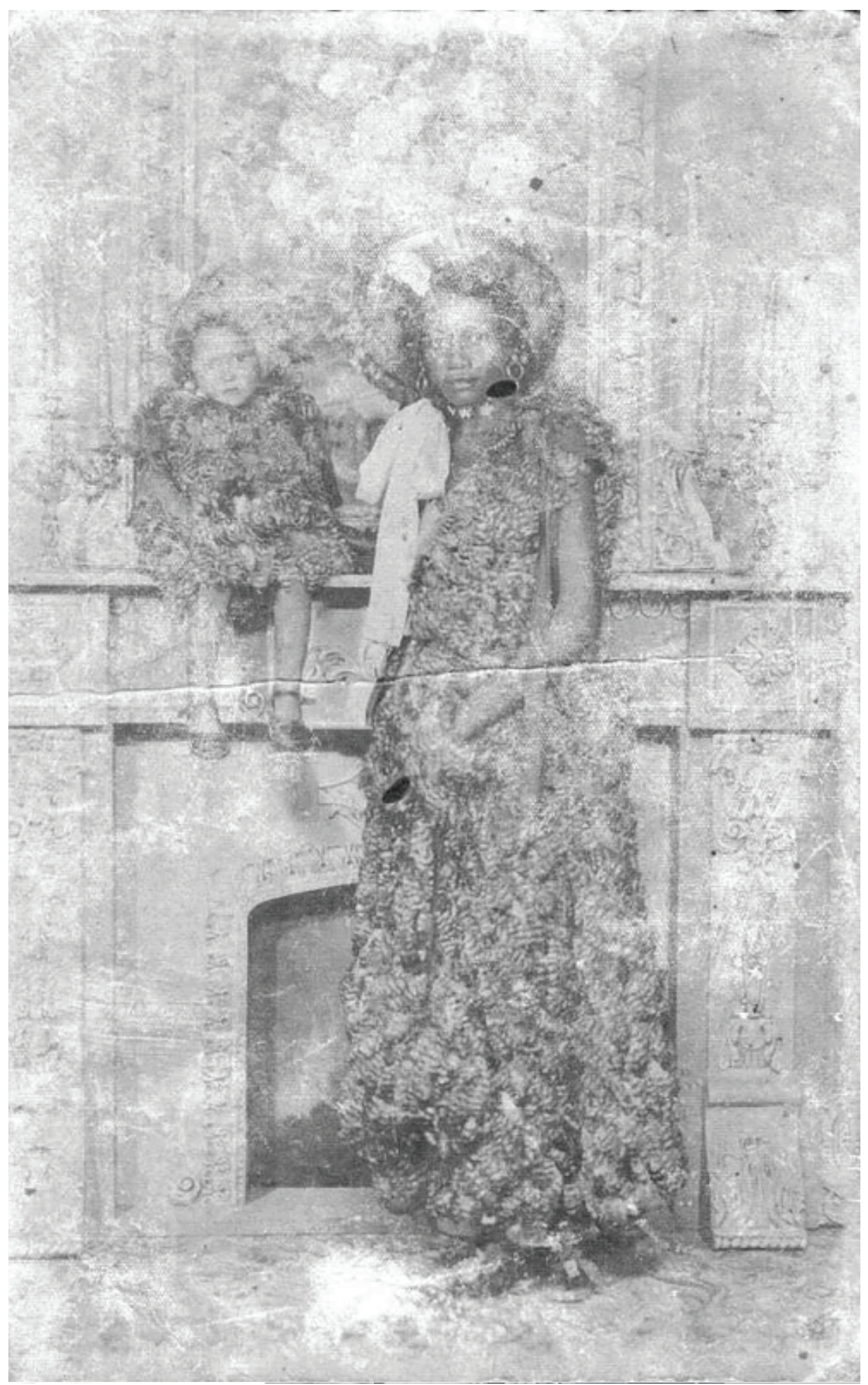

Carolina Maria de Jesus e sua filha Vera Eunice fantasiadas. Disponível em: $<$ https://www.vidaporescrito.com/>. 